\title{
Effects of Altitude and Temperature on Erythrocyte Morphology of Emys orbicularis (Linnaeus, 1758) and Mauremys rivulata (Valenciennes, 1833)
}

\author{
Yusuf BAYRAKCI ${ }^{*}$, Melodi YENMIŞis1, Ahmet MERMER ${ }^{1}$, Cemal Varol TOK², Dinçer AYAZ1 \\ ${ }^{1}$ Ege University, Department of Biology, Faculty of Science, Izmir, Turkey \\ ${ }^{2}$ Çanakkale Onsekiz Mart University, Department of Biology, Faculty of Science, Çanakkale, Turkey \\ ORCID ID: Yusuf BAYRAKCI: https:/ / orcid.org/0000-0001-5992-0643; Melodi YENMiŞ: https:/ / orcid.org/0000-0003-2627-6008; Ahmet \\ MERMER: https:// orcid.org/0000-0002-8740-7617; Cemal Varol TOK: https:// orcid.org/0000-0001-9323-9157; Dinçer AYAZ: \\ https://orcid.org/0000-0002-2667-8106
}

\begin{abstract}
Received: 02.12 .2020
Accepted: 02.03 .2021

Published online: 31.03 .2021

Issue published: 30.06 .2021

Abstract: The decrease in erythrocyte size of animals live at high altitudes yields an evolutionary advantage to survive by providing adaptation to colder temperatures and low partial oxygen pressures. We examined the effect of geographical changes on the erythrocyte morphology of two terrapins, Emys orbicularis and Mauremys rivulata, and analyzed whether such erythrocyte characteristics as size and volume changed at high altitudes and different temperatures. We found out that the erythrocyte characteristics varied both within and between the populations. They varied depending on altitude for $E$. orbicularis and on temperature for $M$. rivulata. However, the erythrocyte characteristics were not correlated with the environmental parameters, except between sunshine duration and erythrocyte length, size, and nucleus volume for $E$. orbicularis.
\end{abstract}

Keywords: Hematology, blood cell, European pond turtle, Caspian turtle.

\section{Yükseklik ve Sıcaklığın Emys orbicularis (Linnaeus, 1758) ve Mauremys rivulata (Valenciennes, 1833)'nın Eritrosit Morfolojisi Üzerine Etkisi}

\begin{abstract}
Öz: Yüksek rakımlarda yaşayan hayvanlarda eritrosit boyutlarındaki azalma, düşük sıcaklıklara ve düşük kısmi oksijen basıncına adaptasyon sağlayarak hayatta kalmalarına evrimsel bir avantaj kazandırmaktadır. Coğrafik değişikliklerin eritrosit morfolojisi üzerindeki etkilerini iki tatlısu kaplumbağası türü olan Emys orbicularis ve Mauremys rivulata' da inceledik ve boyut ve hacim gibi eritrosit özelliklerinin yüksek rakım ve farklı sıcaklıklarda değişip değişmediğini analiz ettik. Eritrosit özelliklerinin hem populasyon içerisinde hem de populasyonlar arasında farklılık gösterdiğini belirledik. E. orbicularis için yüksekliğe bağlı olarak, $M$. rivulata içinse sıcaklığa bağlı olarak değişiklik göstermektedir. Bununla birlikte, E. orbicularis için güneşlenme süresi ile eritrosit uzunluğu, büyüklüğü ve nukleus hacmi arasındaki korelasyon dışında, eritrosit özellikleri ile çevresel parametreler arasında korelasyon görülmemektedir.
\end{abstract}

Anahtar kelimeler: Hematoloji, kan hücresi, Benekli Kaplumbağa, Çizgili Kaplumbağa.

\section{Introduction}

High-altitude habitats force animals to adapt to low oxygen levels ( $\mathrm{Lu}$ et al., 2015). These animals must maintain the balance between $\mathrm{O}_{2}$ supply and $\mathrm{O}_{2}$ demand (Ramirez et al., 2007; Storz et al., 2010). When $\mathrm{O}_{2}$ is lower than needed, all vertebrates face death owing to its essential role for brain functions (Lutz \& Kabler, 1997). Lower vertebrates are prone to survive at low $\mathrm{O}_{2}$ levels due to the efficient anaerobic periods in short terms; however, turtles are even more resilient since their anaerobic periods can be much longer than those of the other animals (Jackson, 2002). High-altitude environments lead to physiological difficulties for animals due to the harsh conditions particularly colder temperatures and low partial oxygen pressures $\left(\mathrm{P}_{\mathrm{O} 2}\right)$ as compared to low-altitude environments (Storz \& Moriyama, 2008; Su et al., 2018). High-altitude hypoxia leads to an increase in the number of erythrocytes (Su et al., 2018). Vertebrates have a capacity to endure high altitudes and manage to survive despite the decreases in $\mathrm{O}_{2}$ tension that potentially restrict the aerobic life (Samaja et al., 2003; Weber, 2007). Although some investigations stated slight or no correlation between blood parameters and altitudinal distribution in reptiles (e.g. Dessauer, 1970; Ruiz et al., 1993), others showed higher hematologic values in upland-distributed species (Vinegar \& Hillyard, 1972). The variation in erythrocyte sizes with regard to altitudinal differences may be explained by the effect of surface on gas exchange; for example, a small blood cell permits more gas exchange than a larger one. As in anurans, the ones that live at higher altitudes have smaller erythrocytes (Baraquet et al., 2013). Temperature is another important factor that affects the blood parameters and the number of the red blood cells. Hemoglobin contents increase in cold environments whereas they decrease at warmer temperatures (Washburn \& Huston, 1968; Moye et al., 1969).

Haematology of Anatolian terrapins were studied previously (e.g., Yılmaz \& Tosunoğlu, 2010; Tosunoğlu et al., 2011). Some of these studies focused on the erythrocyte morphology (e.g., Metin et al., 2006; Arıkan \& Çiçek, 2010; Çiçek et al., 2015), but none of them discussed the effects of environmental factors. Herein, we aimed to understand the relationship between geographical and environmental factors, such as altitude, temperature, precipitation, and sunshine duration differences, and the erythrocyte morphology of E. orbicularis and M. rivulata. 


\section{Material and Methods}

We conducted field surveys at seven localities in southern Anatolia (Table 1). All the populations of E. orbicularis varied by altitude [0-1193 m above sea level (asl)] as well as mean temperature, annual precipitation, and sunshine duration (between 1940 and 2019; the Turkish State Meteorological Service). The three populations of $M$. rivulata were similar in terms of altitude ( 0 and $11 \mathrm{~m}$ asl); therefore, we compared them with regard to other environmental variables.

Table 1. Environmental characteristics of study sites and the number of specimens sampled for each location.

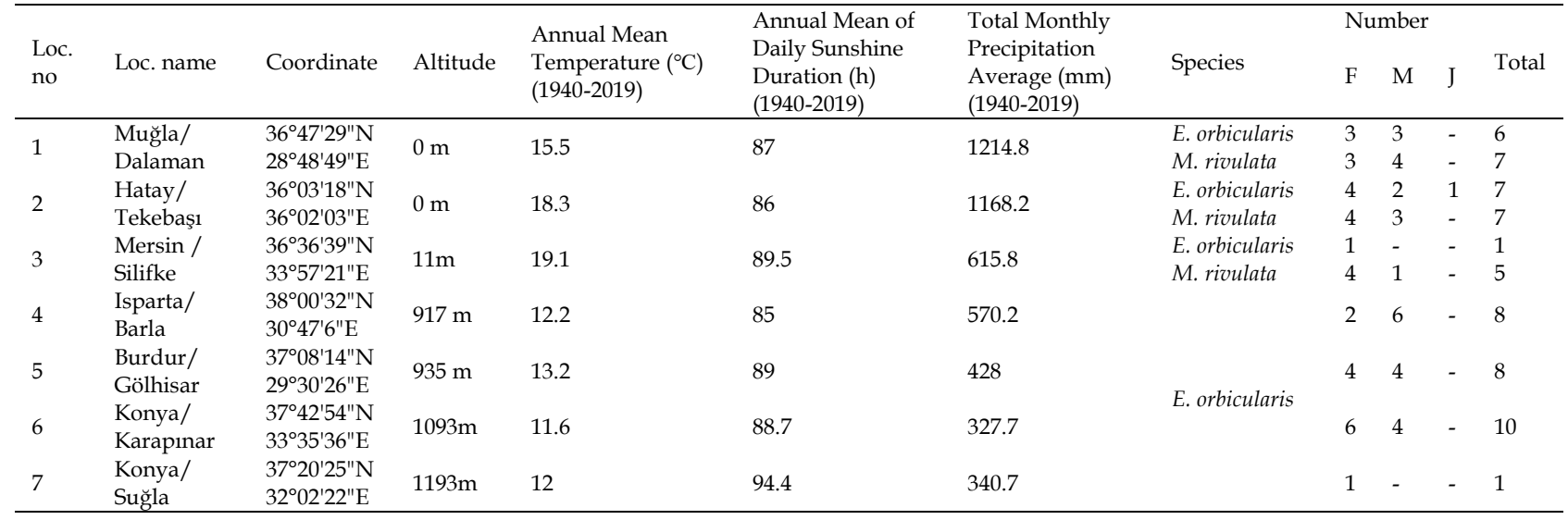

The current study was conducted in the context of the project that was confirmed by Animal Ethics Committee of Ege University (Approval number: 2010-013). We collected blood samples from the caudal vein by using heparinized glass capillaries. Five to ten blood smears were prepared immediately for each individual and all individuals were released after the blood samples had been collected. The prepared blood smears were stained with Wright's stain. For each blood smear, 40 erythrocytes were chosen randomly and measured by using an eyepiece ocular micrometer (Olympus CX31). Erythrocyte length (EL), erythrocyte width (EW), nuclear length (NL), and nuclear width (NW) were measured. The volumes of erythrocytes $(\mathrm{EV})$ and their nuclei (NV) were calculated according to the following formulae: $\mathrm{EV}=\left(\mathrm{EL} \times \mathrm{EW}^{2}\right) \times(\Pi / 6)\left[\mu \mathrm{m}^{3}\right]$ and $\mathrm{NV}=\left(\mathrm{NL} \times \mathrm{NW}^{2}\right) \times(\Pi / 6)\left[\mathrm{m}^{3}\right]$. In addition, the nucleocytoplasmic ratios (NR) were calculated according to the following formula: NR = NV / (EV - NV) (Uca, Arıkan, \& Çiçek, 2017). The blood smears of $41 \mathrm{E}$. orbicularis and $19 \mathrm{M}$. rivulata specimens were examined.

All statistical analyses were performed by PAST vers.3 (Hammer et al., 2001). Normality of the measurements was tested by using the KolmogorovSmirnov D test. If the data set was distributed normally (Kolmogorov-Smirnov D test, $\mathrm{P} \geq 0.05$ ), then parametric tests were used for comparison. The correlations between erythrocyte characteristics and environmental parameters were compared via the Spearman correlation test.

\section{Results}

The erythrocytes of both E. orbicularis and M. rivulata are ellipsoidal and have an ellipsoidal nucleus located at the center of the cell (Fig. 1 and 2). The cytoplasms are yellowish pink and the nuclei are dark purple due to Wright's stain.

The comparison of E. orbicularis populations showed that the mean EL, EW, and EV were minimum at Loc3 which was the hottest locality with the annual mean temperature of $19.1^{\circ} \mathrm{C}$. The mean NL, NW, NS, and NV were minimum while the mean $\mathrm{EW}, \mathrm{EV}$, and $\mathrm{ES}$ were maximum at Loc4 which had the minimum sunshine duration.

Loc6 and Loc7 have similar environmental characteristics such as temperature, precipitation, and altitude because of their proximity. They are both situated in the same province, Konya. They have the minimum annual mean temperature and the total monthly precipitation average while having the maximum altitude among the study sites. All the mean nuclear measurements were maximum at these two localities (Table 2). However, there is only one environmental parameter, sunshine duration, correlated to EL, ES, and NV. While ES and NV were positively affected from sunshine duration, EL was affected negatively. Apart from this, there is no statistically significant correlation detected between erythrocyte morphology and the other environmental parameters (Table 4).

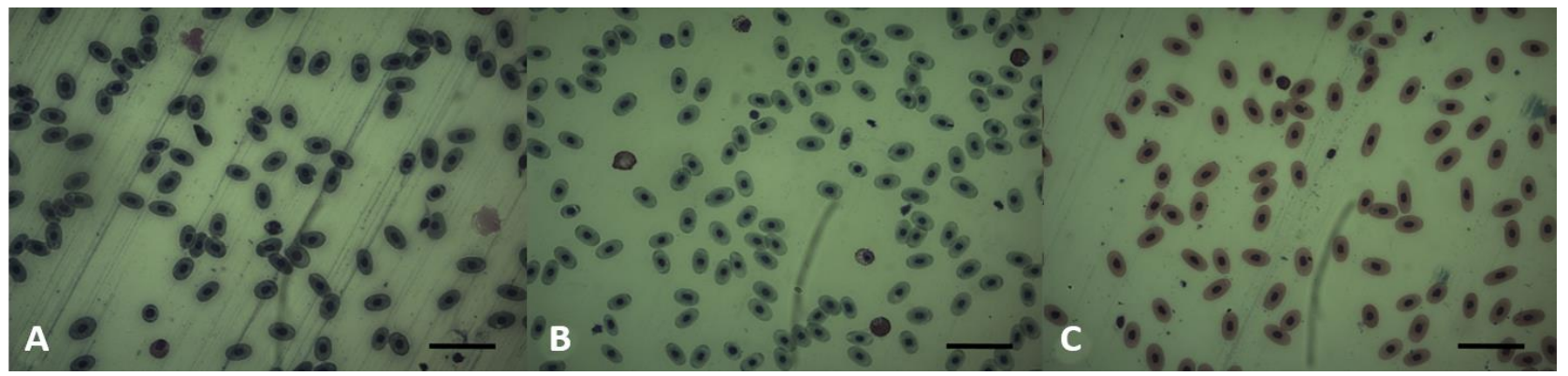

Figure 1. Photomicrographs of Emys orbicularis erythrocytes from A. Loc7 (1193 m asl); B. Loc1 (0 m asl) and C. Loc2 (0 m asl). Horizontal bar: $20 \mu \mathrm{m}$. 


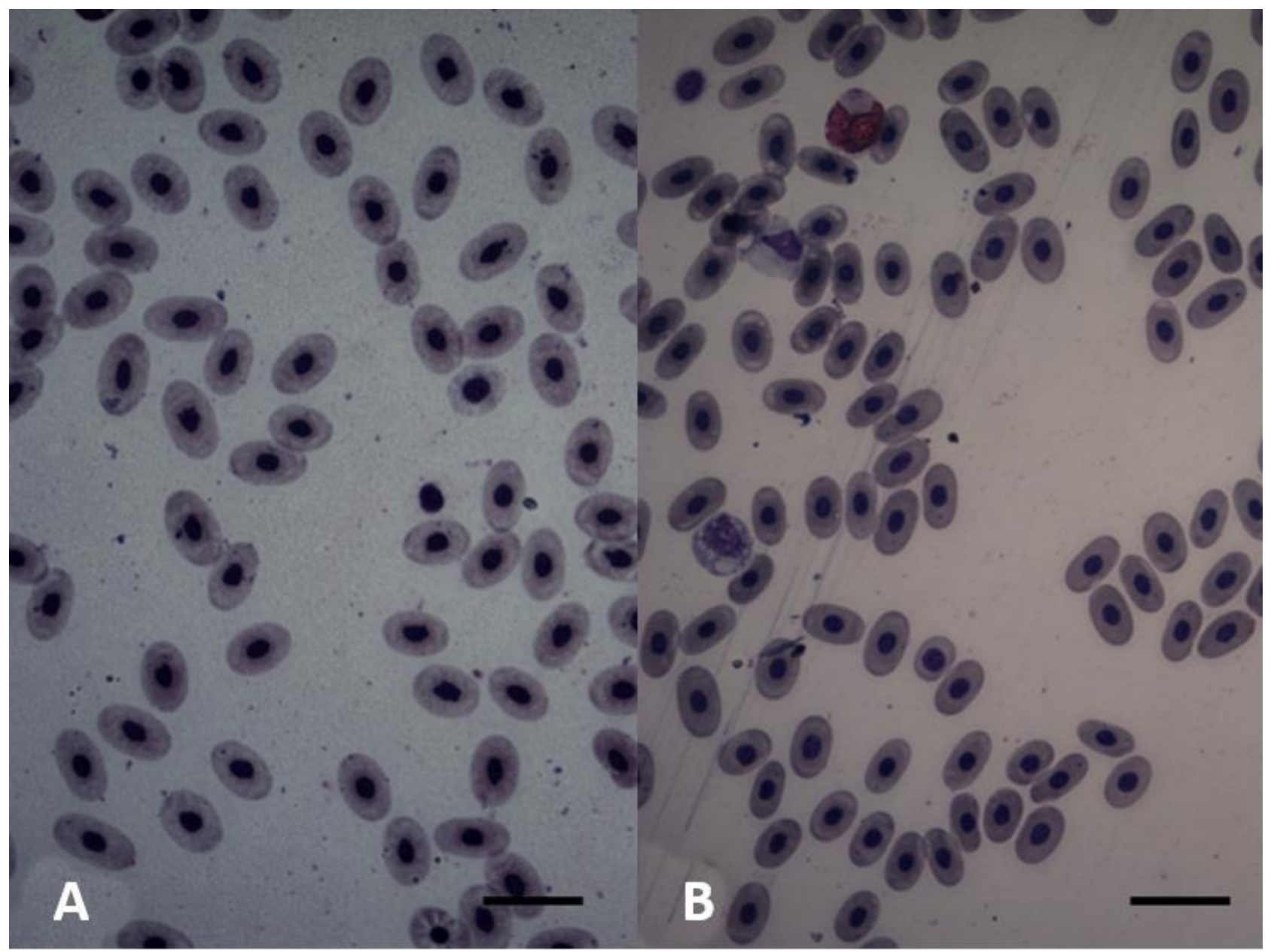

Figure 2. Photomicrographs of Mauremys rivulata from A. Loc1 and B. Loc3. Horizontal bar: $20 \mu \mathrm{m}$.

Because of all the populations of $M$. rivulata studied were at sea level, we did not compare them in terms of altitude. All measurements except NR were maximum at Loc1 which was the westernmost locality with the minimum annual mean temperature among the study sites. Moreover, all the values except EW were minimum at Loc3 which have the maximum annual mean temperature but the minimum sunshine duration and annual mean precipitation. Although Loc2 was the easternmost locality, measurements from this population have average results except EW and NR (see Table 3).
Furthermore, there is no statistically significant correlation detected between erythrocyte characteristics and the environmental parameters for $M$. rivulata.

\section{Discussion}

Environmental conditions like season, geographical position, mean temperature, and precipitation influence many physiological processes such as age, sex, reproduction, and blood parameters of vertebrates (Moye et al., 1969; Jacobson, 2007). Erythrocytes are the transporters of oxygen and carbon dioxide.

Table 2. The mean erythrocyte measurements of Emys orbicularis.

\begin{tabular}{|c|c|c|c|c|c|c|c|c|c|c|c|c|}
\hline $\begin{array}{l}\text { Measurement } \\
\text { Locality }\end{array}$ & $\begin{array}{l}\text { EL } \\
(\mu \mathrm{m})\end{array}$ & $\begin{array}{l}\text { EW } \\
(\mu \mathrm{m})\end{array}$ & EL/EW & $\begin{array}{l}\text { NL } \\
(\mu \mathrm{m})\end{array}$ & $\begin{array}{l}\text { NW } \\
(\mu \mathrm{m})\end{array}$ & $\begin{array}{l}\text { NL/NW } \\
(\mu \mathrm{m})\end{array}$ & $\begin{array}{l}\text { NS } \\
\left(\mu \mathrm{m}^{2}\right)\end{array}$ & $\mathrm{ES}\left(\mu \mathrm{m}^{2}\right)$ & $\begin{array}{l}\text { NS/ES } \\
\left(\mu \mathrm{m}^{2}\right)\end{array}$ & $\mathrm{NR}\left(\mu \mathrm{m}^{3}\right)$ & $\mathrm{EV}\left(\mu \mathrm{m}^{3}\right)$ & $\begin{array}{l}\text { NV } \\
\left(\mu \mathrm{m}^{3}\right)\end{array}$ \\
\hline \multirow{2}{*}{ Loc1 } & 19.56 & 11.15 & 1.76 & 5.59 & 4.29 & 1.32 & 19.20 & 174.71 & 0.11 & 0.047 & 1291.25 & 57.72 \\
\hline & \pm 1.84 & \pm 1.04 & \pm 0.19 & \pm 0.76 & \pm 0.76 & \pm 0.15 & \pm 5.77 & \pm 26.11 & \pm 0.03 & \pm 0.022 & \pm 300.68 & \pm 28.71 \\
\hline \multirow{2}{*}{ Loc2 } & 20.37 & 11.25 & 1.83 & 5.72 & 4.23 & 1.38 & 19.05 & 180.34 & 0.10 & 0.044 & 1373.56 & 55.26 \\
\hline & \pm 1.73 & \pm 1.29 & \pm 0.25 & \pm 0.77 & \pm 0.68 & \pm 0.29 & \pm 4.09 & \pm 27.6 & \pm 0.02 & \pm 0.018 & \pm 352.99 & \pm 19.48 \\
\hline \multirow{2}{*}{ Loc3 } & 18.09 & 10.12 & 1.80 & 5.50 & 4.28 & 1.30 & 18.58 & 143.9 & 0.13 & 0.0105 & 928.02 & 54.42 \\
\hline & \pm 1.26 & \pm 1.05 & \pm 0.24 & \pm 0.73 & \pm 0.62 & \pm 0.22 & \pm 4.14 & \pm 19.29 & \pm 0.03 & \pm 0.003 & \pm 227.81 & \pm 19.19 \\
\hline \multirow{2}{*}{ Loc4 } & 19.91 & 11.87 & 1.69 & 5.46 & 3.94 & 1.39 & 16.94 & 186.09 & 0.09 & 0.0326 & 1493.71 & 45.30 \\
\hline & \pm 1.57 & \pm 1.28 & \pm 0.19 & \pm 0.77 & \pm 0.47 & \pm 0.24 & \pm 3.23 & \pm 27.82 & \pm 0.17 & \pm 0.0112 & \pm 369.68 & \pm 13.77 \\
\hline \multirow{2}{*}{ Loc5 } & 19.08 & 11.80 & 1.63 & 5.53 & 4.32 & 1.30 & 18.80 & 177.35 & 0.10 & 0.0425 & 1418.32 & 55.48 \\
\hline & \pm 1.58 & \pm 1.35 & \pm 0.20 & \pm 0.74 & \pm 0.65 & \pm 0.25 & \pm 3.92 & \pm 28.79 & \pm 0.02 & \pm 0.0168 & \pm 379.38 & \pm 19.13 \\
\hline \multirow{2}{*}{ Loc6 } & 19.81 & 11.08 & 1.80 & 5.92 & 4.25 & 1.41 & 19.90 & 172.96 & 0.11 & 0.0489 & 1302.81 & 58.00 \\
\hline & \pm 1.86 & \pm 1.40 & \pm 0.22 & \pm 0.71 & \pm 0.62 & \pm 0.22 & \pm 4.38 & \pm 30.29 & \pm 0.02 & \pm 0.0186 & \pm 426.42 & \pm 21.18 \\
\hline \multirow{2}{*}{ Loc7 } & 18.81 & 11.68 & 1.62 & 6.00 & 4.53 & 1.35 & 21.34 & 173 & 0.12 & 0.0525 & 1367.46 & 65.62 \\
\hline & \pm 1.32 & \pm 1.28 & \pm 0.18 & \pm 0.70 & \pm 0.61 & \pm 0.25 & \pm 3.84 & \pm 26.02 & \pm 0.02 & \pm 0.0175 & \pm 359.24 & \pm 18.65 \\
\hline \multirow{2}{*}{ Total } & 19.67 & 11.42 & 1.74 & 5.65 & 4.21 & 1.36 & 18.81 & 176.94 & 0.10 & 0.0423 & 1370.02 & 54.45 \\
\hline & \pm 1.77 & \pm 1.34 & \pm 0.22 & \pm 0.77 & \pm 0.65 & \pm 0.24 & \pm 4.39 & \pm 28.95 & \pm 0.02 & \pm 0.0191 & \pm 380.36 & \pm 21.04 \\
\hline
\end{tabular}


Table 3. The mean erythrocyte measurements of Mauremys rivulata.

\begin{tabular}{|c|c|c|c|c|c|c|c|c|c|c|c|c|}
\hline $\begin{array}{l}\text { Measurement* } \\
\text { Locality }\end{array}$ & $\begin{array}{l}\text { EL } \\
(\mu \mathrm{m})\end{array}$ & $\begin{array}{l}\text { EW } \\
(\mu \mathrm{m})\end{array}$ & $\begin{array}{l}\text { EL/EW } \\
(\mu \mathrm{m})\end{array}$ & $\begin{array}{l}\text { NL } \\
(\mu \mathrm{m})\end{array}$ & $\begin{array}{l}\text { NW } \\
(\mu \mathrm{m})\end{array}$ & $\begin{array}{l}\text { NL/NW } \\
(\mu \mathrm{m})\end{array}$ & $\begin{array}{l}\text { NS } \\
\left(\mu \mathrm{m}^{2}\right)\end{array}$ & $\mathrm{ES}\left(\mu \mathrm{m}^{2}\right)$ & $\begin{array}{l}\text { NS/ES } \\
\left(\mu \mathrm{m}^{2}\right)\end{array}$ & $\mathrm{NR}\left(\mu \mathrm{m}^{3}\right)$ & $\mathrm{EV}\left(\mu \mathrm{m}^{3}\right)$ & $\begin{array}{l}\text { NV } \\
\left(\mu \mathrm{m}^{3}\right)\end{array}$ \\
\hline \multirow{2}{*}{ Loc1 } & 20.47 & 11.58 & 1.78 & 6.49 & 4.65 & 1.41 & 23.80 & 186.44 & 0.12 & 0.0563 & 1456.85 & 75.44 \\
\hline & \pm 1.49 & \pm 1.17 & \pm 0.19 & \pm 0.92 & \pm 0.62 & \pm 0.27 & \pm 4.96 & \pm 25.77 & \pm 0.02 & \pm 0.0185 & \pm 342.87 & \pm 23.53 \\
\hline \multirow{2}{*}{ Loc2 } & 18.62 & 10.69 & 1.76 & 5.85 & 4.47 & 1.33 & 20.66 & 156.29 & 0.13 & 0.0627 & 1125.48 & 63.28 \\
\hline & \pm 1.52 & \pm 1.09 & \pm 0.23 & \pm 0.82 & \pm 0.67 & \pm 0.25 & \pm 4.65 & \pm 20.16 & \pm 0.03 & \pm 0.0259 & \pm 246.90 & \pm 21.81 \\
\hline \multirow{2}{*}{ Loc3 } & 17.50 & 10.93 & 1.61 & 5.74 & 4.23 & 1.37 & 19.20 & 150.30 & 0.12 & 0.0555 & 1105.36 & 55.76 \\
\hline & \pm 1.27 & \pm 0.99 & \pm 0.18 & \pm 0.75 & \pm 0.63 & \pm 0.22 & \pm 4.36 & \pm 18.09 & \pm 0.03 & \pm 0.0248 & \pm 222.94 & \pm 20.75 \\
\hline \multirow{2}{*}{ Total } & 18.83 & 11.02 & 1.72 & 6.01 & 4.45 & 1.37 & 21.15 & 163.40 & 0.13 & 0.0587 & 1217.02 & 64.65 \\
\hline & \pm 1.84 & \pm 1.15 & \pm 0.22 & \pm 0.89 & \pm 0.67 & \pm 0.25 & \pm 5.00 & \pm 26.18 & \pm 0.03 & \pm 0.0238 & \pm 313.27 & \pm 23.29 \\
\hline
\end{tabular}

Table 4. Correlation between erythrocyte morphology and environmental parameters according to spearman rho test (Bold values indicate statistically significance).

\begin{tabular}{|c|c|c|c|c|c|c|c|c|c|c|c|c|c|}
\hline & & $\begin{array}{l}\text { EL } \\
(\mu \mathrm{m})\end{array}$ & $\begin{array}{l}\text { EW } \\
(\mu \mathrm{m})\end{array}$ & $\begin{array}{l}\text { EL/EW } \\
(\mu \mathrm{m})\end{array}$ & $\begin{array}{l}\text { EV } \\
\left(\mu \mathrm{m}^{3}\right)\end{array}$ & $\begin{array}{l}\text { ES } \\
\left(\mu \mathrm{m}^{2}\right)\end{array}$ & $\begin{array}{l}\text { NL } \\
(\mu \mathrm{m})\end{array}$ & $\begin{array}{l}\text { NW } \\
(\mu \mathrm{m})\end{array}$ & $\begin{array}{l}\text { NL/NW } \\
(\mu \mathrm{m})\end{array}$ & $\begin{array}{l}\text { NV } \\
\left(\mu \mathrm{m}^{3}\right)\end{array}$ & $\begin{array}{l}\text { NS } \\
\left(\mu \mathrm{m}^{2}\right)\end{array}$ & $\begin{array}{l}\text { NS/ES } \\
\left(\mu \mathrm{m}^{2}\right)\end{array}$ & $\begin{array}{l}\text { NR } \\
\left(\mu \mathrm{m}^{3}\right)\end{array}$ \\
\hline \multirow[t]{2}{*}{ Altitude } & cc & -0.342 & 0.234 & -0.618 & 0.414 & 0.414 & 0.218 & 0.414 & -0.288 & 0.183 & 0.450 & 0.198 & 0.541 \\
\hline & $\mathrm{p}$ & 0.452 & 0.613 & 0.139 & 0.355 & 0.355 & 0.638 & 0.355 & 0.531 & 0.694 & 0.310 & 0.670 & 0.210 \\
\hline Annual Mean & cc & -0.143 & -0.321 & 0.468 & -0.464 & -0.107 & -0.631 & -0.500 & 0.000 & 0.145 & -0.643 & -0.321 & -0.571 \\
\hline Temperature $\left({ }^{\circ} \mathrm{C}\right)$ & $\mathrm{p}$ & 0.760 & 0.482 & 0.289 & 0.294 & 0.819 & 0.129 & 0.253 & 1.000 & 0.756 & 0.119 & 0.482 & 0.180 \\
\hline Annual Mean of Daily & cc & -0.893 & -0.321 & -0.396 & 0.393 & 0.821 & -0.523 & 0.429 & -0.750 & 0.800 & 0.250 & -0.464 & 0.536 \\
\hline Sunshine Duration (h) & $\mathrm{p}$ & 0.007 & 0.482 & 0.379 & 0.383 & 0.023 & 0.229 & 0.337 & 0.052 & 0.031 & 0.589 & 0.294 & 0.215 \\
\hline Total Monthly & cc & 0.179 & -0.143 & 0.396 & -0.393 & -0.214 & -0.360 & -0.357 & 0.286 & -0.091 & -0.393 & -0.214 & -0.464 \\
\hline $\begin{array}{l}\text { Precipitation Average } \\
(\mathrm{mm})\end{array}$ & $\mathbf{p}$ & 0.702 & 0.760 & 0.379 & 0.383 & 0.645 & 0.427 & 0.432 & 0.535 & 0.846 & 0.383 & 0.645 & 0.294 \\
\hline
\end{tabular}

*EL: Erythrocyte Length; EW: Erythrocyte Width; NL: Nucleus Length; NW: Nucleus Width; NS: Nucleus Size; ES: Erythrocyte Size; NR: Nucleocytoplasmic Ratio; EV: Erythrocyte Volume; NV: Nucleus Volume.

** cc: correlation coefficient; p: significance level

The size and shape of erythrocytes influence the efficiency and rate of gas exchange (Hartman \& Lessler, 1964). Small cells have a larger surface/volume ratio than large cells have; thus, they have a greater rate of oxygen exchange than larger ones do (Stacy et al., 2011; Javanbakht et al., 2013).

Because erythrocytes play an essential role in vertebrate physiology, it is important to understand their morphological variations to be able to identify changes depending on the environmental factors. Changes in temperature and rainfall affect food availability which influences the metabolism of ectotherms (e.g., Litzgus, \& Hopkins, 2003; Setlalekgomo et al., 2012).

The increase in the number of red blood cells depending on altitude is an adaptation to be able to provide more gas exchange in a relatively short time. Therefore, the size and volume of the erythrocytes decrease at higher altitudes (Ramirez et al., 2007) whereas the number increases. Lu et al. (2015) reported that Phrynocephalus erythrurus, a reptile that lives at high altitudes, has more erythrocytes with less cell volume than those living at low altitudes. Accordingly, similar results were found for the Tibetan chicken (Su et al., 2018). Temperature is another factor that affects cell morphology. It has been known that the erythrocyte volumes and sizes increase at colder temperatures (e.g., Washburn \& Huston, 1968; Moye et al., 1969). In parallel with these results, we calculated the minimum erythrocyte sizes and volumes from Loc3.

We found out that the mean values of erythrocyte sizes and volumes of E. orbicularis varied among the study sites; however, these variations did not correlate with environmental changes. There was a difference of $1193 \mathrm{~m}$ between the lowest and highest localities; yet, we discovered that the minimum and maximum values of the measurements were at Loc3 and Loc4, respectively. Altitude difference between these localities is $906 \mathrm{~m}$, nearly the same between Loc1 and Loc7, but the annual mean temperature difference is nearly twice than those between Loc1 and Loc7 $\left(3.5^{\circ} \mathrm{C}\right.$ between Loc1-Loc7, $7.1^{\circ} \mathrm{C}$ between Loc3-Loc4). Thus, we concluded that the temperature also affects the erythrocyte sizes but we do not have correlation on erythrocyte morphology for our sample.

Making a comparison of erythrocyte sizes with the literature is not straightforward because few studies indicate in which altitude the samples were taken and the others do not provide any information about environmental parameters. For this reason, it is not possible to discuss all environmental factors with the published literature. Maximum values for EL and ES were reported $22.5 \mu \mathrm{m}, 249.4 \mu \mathrm{m}^{2}$ respectively for Emys trinacris (Arizza et al., 2014). Maximum ES for Anatolian populations of E. orbicularis is $225.1 \mu \mathrm{m}^{2}$ reported from captive specimens (Metin et al., 2006).

Our results indicated that sunshine duration positively correlate with ES and NV whereas negatively correlate with EL for E. orbicularis. This means the turtles have longer sunshine duration, have much bigger spherical erythrocytes, and have larger nucleus volume. Basking is a common behavior in ectotherms and many freshwater turtles bask either at the surface of the water or on the substrates (Bulté \& Blouin-Demers, 2010). Sunshine duration becomes crucial for regulation of metabolic rate to this respect. Bulté \& Blouin-Demers (2010) suggested that basking behavior allows turtles to increase their metabolic rate by up to $30.1 \%$.

Erythrocytes of $M$. rivulata were large both in size and in volume at Loc1, while they were small at warmer Loc3. Because of the altitudes were the same among the localities of $M$. rivulata, the differences between the Loc1 and Loc3 were temperature which could be an effective environmental variable on erythrocyte morphology and precipitation. Loc1 had been a cooler habitat with more rainfall for the turtles in which we measured larger cells and nuclei. 
In conclusion, our results support the literature knowledge that the temperature and the altitude affect the erythrocyte sizes. The turtles living in the higher temperature or/and elevation are tend to have smaller erythrocyte sizes. However, these variations on erythrocyte sizes do not correlate with environmental parameters in all studied populations. Further studies with more populations that have various intermediate environmental characteristics are needed for a better point of view.

Acknowledgement: This study was supported by TUBITAK (The Scientific and Technical Research Council of Turkey) [Project No: 110T927]. We would like to thank Dr. Hasan Serdar MUTLU and Oğuzkan CUMHURIYET for their contributions to field studies.

Ethics committee approval: This study was performed in accordance with ethical standards of animal experiments. Legal research ethics committee approval permissions for the study were obtained from the Ege University, Animal Experiments Local Ethics Committee (No: 2010-013).

Conflict of interest: The authors declares that there is no conflict of interest.

\section{References}

Arıkan, H., \& Çiçek, K. (2010). Morphology of peripheral blood cells from various species of Turkish Herpetofauna. Acta Herpetologica, 5(2), 179198. https://doi.org/10.13128/Acta_Herpetol-8526

Arizza, V., Russo, D., Marrone, F., Sacco, F., \& Arculeo. M. (2014). Morphological characterization of the blood cells in the endangered Sicilian endemic pond turtle, Emys trinacris (Testudines: Emydidae). Italian Journal of Zoology, 1-10. https://doi.org/10.1080/11250003.2014.938371

Baraquet, M., Grenat, P.R., Salas, N.E., \& Martino, A.L. (2013). Intraspecific variation in erythrocyte sizes among populations of Hypsiboas cordobae (Anura, Hylidae). Acta Herpetologica, 8, 93-97. https://doi.org/10.13128/Acta_Herpetol-12954

Bulté, G., \& Blouin-Demers, G. (2010). Estimating the energetic significance of basking behaviour in a temperate-zone turtle. Ecoscience, 17(4), 387393. https:// doi.org/10.2980/17-4-3377

Çiçek, K., Arıkan, H., \& Ayaz, D. (2015). Blood Cells Morphology and Erythrocytes Count of Two Freshwater Turtles, Emys orbicularis and Mauremys rivulata, from Turkey. Ecologia Balkanica, 7(1), 21-27.

Dessauer, H.C. (1970). Blood chemistry of reptiles: physiological and evolutionary aspects. Biology of the Reptilia, 3, 1-72.

Hammer, Ø., Harper, D. A., \& Ryan, P. D. (2001). PAST: Paleontological statistics software package for education and data analysis. Palaeontologia electronica, 4(1), 9.

Hartman, F.A., \& Lessler, M.A. (1964). Erythrocyte measurements in fishes amphibia, and reptiles. The Biological Bulletin, 126(1), 83-88.

Jackson, D.C. (2002). Hibernating without oxygen: physiological adaptations of the painted turtle. Journal of Physiology, 543, 731-737.

Jacobson, E.R. (2007). Infectious diseases and pathology of reptiles. Boca Raton, Florida, CRC Press, 716 pp.

Javanbakht, H., Vaissi, S., \& Parto, P. (2013). The morphological characterization of the blood cells in the three species of turtle and tortoise in Iran. Research in Zoology, 3, 38-44. https://doi.org/10.5923/j.zoology.20130301.06

Litzgus, J.D., \& Hopkins, W.A., (2003). Effect of temperature on metabolic rate of the mud turtle (Kinosternon subrubrum). Journal of Thermal Biology, 28, 595- 600. https://doi.org/10.1016/j.jtherbio.2003.08.005

Lu, S., Xin, Y., Tang, X., Yue, F., Wang, H., Bai, Y., \& Chen, Q. (2015). Differences in hematological traits between high-and low-altitude lizards (genus Phrynocephalus). PLoS One, 10, e0125751. https:// doi.org/10.1371/journal.pone.0125751

Lutz, P.L., \& Kabler, S. (1997). Release of adenosine and ATP in the brain of the freshwater turtle (Trachemys scripta) during long-term anoxia. Brain Research, 769, 281-286. https:// doi.org/10.1016/S0006-8993(97)00719-1

Metin, K., Türkozan, O., Kargın, F., Basumoglu, Y.K., Taşkavak, E., \& Koca, S. (2006). Blood cell morphology and plasma biochemistry of the captive European pond turtle Emys orbicularis. Acta Veterinaria Brno, 75(1), 4955. https://doi.org/10.2754/avb200675010049
Moye Jr, R.J., Washburn, K.W., \& Huston, T.M. (1969). Effects of environmental temperature on erythrocyte numbers and size. Poultry science, 48(5), 1683-1686. https://doi.org/10.3382/ps.0481683

Ramirez, J.M., Folkow, L.P., \& Blix, A.S. (2007), Hypoxia tolerance in mammals and birds: from the wilderness to the clinic. Annual Review of Physiology, 69, 113-143.

Ruiz, G., Rosenmann, M., \& Nuñez, H. (1993). Blood values in South American lizards from high and low altitudes. Comparative Biochemistry $\mathcal{E}$ Physiology, 106, 713-718. https://doi.org/10.1016/03009629(93)90386-I

Samaja, M., Crespi, T., Guazzi, M., \& Vandegriff, K.D. (2003). Oxygen transport in blood at high altitude: role of the hemoglobin-oxygen affinity and impact of the phenomena related to hemoglobin allosterism and red cell function. European Journal of Applied Physiology, 90, 351-359. https://doi.org/10.1007/s00421-003-0954-8

Setlalekgomo, M.R., Winter, P.E.D., \& Els, S.F., (2012). The metabolic adjustments of the angulate tortoise (Chersina angulata) to seasonal changes in temperature and photoperiod. Journal of Applied Sciences Research, 8, 1211-1218.

Stacy, N.I., Alleman, A.R., \& Sayler, K.A. (2011). Diagnostic haematology of reptiles. Clinics in Laboratory Medicine, 31, 87-108. https://doi.org/10.1016/j.cll.2010.10.006

Storz, J.F., \& Moriyama, H. (2008). Mechanisms of hemoglobin adaptation to high altitude hypoxia. High Altitude Medicine $\mathcal{E}$ Biology, 9, 148-157. https://doi.org/10.1089/ham.2007.1079

Storz, J.F., Scott, G.R., \& Cheviron, Z.A. (2010). Phenotypic plasticity and genetic adaptation to high-altitude hypoxia in vertebrates. Journal of $\begin{array}{llll}\text { Experimental } \quad \text { Biology, 213, 4125-4136. } & \text {. }\end{array}$ https://doi.org/10.1242/jeb.048181

Su, Y., Li, D., Gaur, U., Chen, B., Zhao, X., Wang, Y., \& Zhu, Q. (2018). The comparison of blood characteristics in low-and high-altitude chickens. Italian Journal of Animal Science, 17, 195-201. https:// doi.org/10.1080/1828051X.2017.1355272

Tosunoğlu, M., Yılmaz, N., \& Gül, C. (2011). Effects of varying ecological conditions on the blood parameters of freshwater turtles in Çanakkale
(Turkey).
Ekoloji,
20
(78),
7-12. https://doi.org/10.5053/ekoloji.2011.782

Uca, O., Arıkan, H., \& Çiçek, K. (2017). Blood cell morphology of Turkish gekkonid lizards. Herpetozoa, 30, 29-37.

Vinegar, A., \& Hillyard, S.D. (1972). The effects of altitude on oxygenbinding parameters of the blood of the iguanid lizards, Sceloporus jarrovi and Sceloporus occidentalis. Comparative Biochemistry and Physiology Part A: Physiology, 43, 317-320. https://doi.org/10.1016/03009629(72)90190-9

Washburn, K.W., \& Huston T.M. (1968). Effect of environmental temperature on iron deficiency anemia in Athens-Canadian

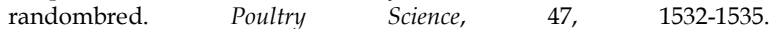
https://doi.org/10.3382/ps.0471532

Weber, R.E. (2007). High-altitude adaptations in vertebrate hemoglobins. Respiratory Physiology \& Neurobiology, 158, 132-142. https://doi.org/10.1016/j.resp.2007.05.001

Yilmaz, N., \& Tosunoğlu, M. (2010). Hematology and some plasma biochemistry values of free-living freshwater turtles (Emys orbicularis and Mauremys rivulata) from Turkey. North-Western Journal of Zoology, 6(1), 109-117. 